\title{
Pre-University Training in Ukraine: History and Contemporary Condition
}

\author{
Iryna Liashenko \\ Ph.D., Associate Professor, Taras Shevchenko National University of Kyiv \\ (Kyiv, Ukraine) \\ E-mail: irina_lyashenko@univ.net.ua \\ ORCID: 0000-0003-3912-2075
}

The article is devoted to the analysis of historical stages of formation, critical problems, perspectives and features of the development of pre-university education in Ukraine at the preparatory departments of universities on the example of the Taras Shevchenko National University of Kyiv. The historiographic description of the development of pre-university education in the system of higher education of Ukraine in the Soviet and post-Soviet times is carried out; the modern functions of the preparatory department are revealed (on the example of the preparatory department of the Taras Shevchenko National University of Kyiv); critical problems, features and prospects of development of pre-university training in the system of higher education of Ukraine are analyzed. The author considered the following critical problems in the development of pre-university education in Ukraine: 1) "overloaded" programs of non-academic study materials; 2) unreasonably large number of institutions of higher education, which causes loss of higher education in the eyes of an applicant; 3) unjustified hyperbole public opinion on the obligatory admission to a higher education institution; 4) an increase in the gap between school education and the requirements of higher education; 5) the entrant's focus on the list of subjects of externality when choosing a future specialty; 6) the limited possibilities of external testing reveal the ability of an entrant to study in a specialty. Author has offered the ways of its solution on the example of the Preparatory Department at Taras Shevchenko National University of Kyiv.

Keywords: pre-university preparation, preparatory department, higher education, university, external independent evaluation

Received: July 27, 2018; accepted: September 1, 2018

Future Human Image, Volume 10, 2018: 41-49.

DOI: $10.29202 / \mathrm{fhi} / 10 / 4$

\section{Introduction}

Pre-university education in Ukraine is carried out on two stages: in the secondary school and in the higher education institutions. Preparatory departments are typical units for the most of Universities and Collages of Ukraine. Sometimes the same function is being provided by preparatory faculties or preparatory courses. The idea of preparatory department originates from

(C) Liashenko, Iryna, 2018 
soviet education system. However, despite of Soviet State collapse, preparatory departments still present within the education system. Their functions and purposes have changed. Authors contend that preparatory department is an effective instrument of heightening of higher education quality despite of its soviet origin.

This article targets to analyze the milestones of historical development, key problems, prospects and peculiarities of pre-university education in Ukrainian higher education system. To attain a target author focuses on the experience of Preparatory department of Taras Shevchenko National University of Kyiv. The assignments of an article are:

1. To enlighten the history of Ukrainian pre-university education development in soviet and post-soviet periods;

2. To describe the modern functions of preparatory department (using the example of Preparatory department of Taras Shevchenko National University of Kyiv);

3. To analyze the key problems, peculiarities and prospects of development of preuniversity education in the system of higher education of Ukraine.

To meet the target of the research, we employ several methods that are: comparative method, historiography method, functional-analytic method and method of exert evaluation. In addition, there are several recent researches whose results were also used as theoretical and methodological basis of the present paper: author's paper on history of philosophy methodology [Liashenko, 2018], papers by Oleg Bazaluk [Bazaluk \& Matusevych, 2014], Paul Montgomery [Montgomery \& Lilly, 2012], Dmytro Nelipa [Nelipa et. al., 2018], Sergii Rudenko [Liashenko \& Rudenko, 2018; Rudenko et. al., 2018], Denys Svyrydenko [Svyrydenko \& Yatsenko, 2018], etc.

\section{History of Ukrainian pre-university education development in soviet and post-soviet periods}

No education system all over the World has such phenomena as preparatory faculties, departments or courses. Nowadays such divisions still exist in the structures of Universities of ex-soviet republics on condition that they were functionally reformed and became more competitive.

There were two types of divisions for pre-university education soviet system of higher education 1) divisions for foreigners; 2) divisions for USSR citizens. Similar function was provided by "Knowledge." Both systems had a definite aim of existence, assignments and purpose. On the territory of Ukraine, those units were firstly united in 1998, when Ukraine was already an independent state [Selected Issues, 2004; Liashenko \& Rudenko, 2018].

Pre-university education divisions for foreigners were founded after The Second World War, when USSR international influence increased. It was a part of the plan for so-called "soviet democracy" building. In the same time, it was perfectly considered scheme of communism popularization in countries in which "capitalistic democracies" were not interested (USA or NATO controlled countries) [Selected Issues, 2004].

Giving a possibility to get a higher education to the citizens of USSR controlled countries raised as a method of ideological struggle. Russian language was defined as a language for international communication, relations and education. Proceeding of ideological strategy required the Russian language competence. For this reason, in 1950-s, the first preparatory department for foreigners was founded in Moscow State University. In this way, due to the "international friendship" agreement, students from "friendly countries" (Warsaw Pact 
countries, Africa, Asia, Latin America) began to study in USSR free of charge [Selected Issues, 2004: 429-438].

In fact, the professional study due to the "international friendship" agreement targeted a propaganda, communism and Russian language expansion. To reach the mentioned grandiose target at the universities all over the country similar preparatory divisions were founded. They prepared foreigners to enter Universities of USSR for study in Russian [Selected Issues, 2004].

In Ukrainian Soviet Socialist Republic the first preparatory department, which prepared foreigners for future university study, was founded in Kyiv University in 1960. Public policy of that time established a total control, for this reason the register of the prospective students has always been formed in Moscow. First students (about one hundred) originated from Asia, Africa and Latin America (mostly from Republic of Cuba). Later more students from Guinea, Indonesia, Togo, Nigeria, Cameroon, Zanzibar and Yemen arrived [Liashenko \& Rudenko, 2018; Selected Issues, 2004: 429-438].

The assignment of the preparatory department was to prepare foreigners for future studies in higher and specialized secondary educational institutions of Soviet Union. The preparation was provided on Humanities, Engineering and Medicine directions. By the time of preparatory department foundation, there were no methodic recommendations, student's books or syllabuses for educating foreigners. All the materials for foreign students were composed and developed by the staff of the department in $1960 \mathrm{~s}$. In addition, they developed the complex strategy of step-by-step formation of foreign student's communicative competences and positive motivation. For this purpose, several specialized chairs were founded within the structure of the department: chairs for the natural sciences, social sciences and Russian language [Selected Issues, 2004: 429-438].

Chair of natural sciences becomes basic for physics and chemistry teaching on the preparatory departments for foreigners all over the Soviet Union. The chair professionals composed unified students' books that were coordinated with Russian language teaching. Mentioned students' books are still in use by the preparatory departments [Liashenko \& Rudenko, 2018].

Social sciences chair had one important additional, not connected to the education, aim. The chair provided social adaptation and formation of the positive attitude to the soviet state and communism for foreign students which supposed to live and study in nonnative cultural and language environment. For this special ideological and propaganda purposes since the middle of 1960s some organizations such as "Council of international friendship", "Club for interesting meetings" were founded and functioned at the preparatory department [Selected Issues, 2004: 429-438].

The first specialized chair of the Russian as a foreign language started teaching in October, 1960. On the position of chairman was invited associated professor Maria Parahina. Russian language chair №1 dealt with the foreign students, who prepared for the study on humanities, engineering and techniques, medicine and biology directions. In this period the department becomes basic for professionals' internship. The staff of the chair composed study plans and syllabuses on Russian and Ukrainian as the foreign languages; developed technologies for foreigners to prepare for nonnative language subject study; developed the methodic for Russian pronunciation practice, which took into the consideration the peculiarities of learners' native languages or mediation languages (Swahili, Dari, Pashto, Vietnamese, Bemba, Indonesian, Lao, Arabian, Spanish ) In 1965 Russian language chair №2 which was separately specialized on Asia, Africa and Latin America humanities students was founded. In 1984 Russian language 
chair №3 which was focused on medicine biology and economics prospective students' preparation started the teaching. An annual scientific journal "The Bulletin of Kyiv University. Methodic of foreign students teaching" was published since 1977 till 1989. In 1990, the staff of the preparatory department consisted of 115 teachers, 7 translators, 30 methodologists and technicians. There were two specialized language laboratories with the modern equipment; classrooms specially equipped for individual students' work and feedback; the library, which contained necessary and contemporary books. More than 500 students from 120 countries were entering the faculty each year [Selected Issues, 2004: 429-438].

After Ukraine became independent and the centralized system of foreigners' education collapsed the preparatory department for foreigners was closed. Humanities and natural sciences chairs of the department were dismissed; staff of the department partly changed the positions within or beyond the University [Selected Issues, 2004: 429-438].

Partly conserved system of foreigners' preparation still operated after 1991. Since 1991, Kyiv University has been taught only in state (Ukrainian) language. The foreigners were persuaded to learn Ukrainian for further study. First students who approved the new course originated from Palestine, Cyprus, Israel, Mongolia and China. The social sciences chair was joint to The Institute of International Relations of Kyiv University, as well as three Russian as foreign language chairs, which were united together within the "Chair of primary Russian language studies". In 1993, the "Chair of primary Russian language studies" changed the name to "Chair of pre-university preparation of foreigners" and was transferred to Linguistics department. In 1998 the "Chair of pre-university preparation of foreigners" was dismissed which caused the decrease of the foreign students in Kyiv University [Selected Issues, 2004: 429-438].

The new phase of the foreigners' preparation study started in 1998, when the preparatory department had been founded. The contingent is being formed in the circumstances of fierce competition with other similar Ukrainian institutions; nevertheless, the quantity of students is sustainably high because of excellent quality of education services.

Preparatory departments (divisions, courses) for native learners have different purpose. They bridge the gap between secondary school and higher education institutions. Such "bridge" is required because there is a tangible gap between the knowledge and competences given by the school and universities requirements. The mentioned gap is a result of an adverse effect of the soviet public administration system on the public administration strategies of independent Ukraine. There were two separate public administration bodies for managing schools and universities, which caused incoherence between school results and university requirements. University entrants where required an additional effort to overcome the gap between school and university [Selected Issues, 2004: 429-438].

Pre-university education organizations appear in 1920s, during the establishment and expansion of soviet power. The first preparatory division in Kyiv University, called "workers department", was founded in 1920 due to the directive of Peoples' Commissar of education for the people who did not have necessary skills and knowledge to enter the university. There is only one existing document, which regulates study plans and strategies. This point may be considered as the moment of foundation of preparatory department in Kyiv University [Selected Issues, 2004: 429-438].

Soviet youth considered the university education as an opportunity not only to get a degree and profession but to change their lives. Establishment of the free-of-charge and available higher education caused the increase of university entrants amount. Further implementation 
of an idea of the pre-university education took place after almost 50 years in 1969. The new preparatory division was specially founded to prepare prospective university entrants which had a working experience and Red Army ex-soldiers. After the collapse of the Soviet Union, the strategy of self-financing, commercial and independent native or foreign customers search came into a priority. The preparatory department was challenged by the fierce competition on internal and international markets. Such circumstances demanded a new administration strategy, which was realized in 1998 by unity of native and foreigners preparatory divisions within the preparatory department. Foreign graduates of the preparatory department received the Certificate, which granted them the right to enter any higher educational institution of Ukraine by the results of the interview without entry exams. After the collapse of the USSR, the system of student exchange due to the "international friendship" programme was provided only on a commercial basis, which decrease the quantity of foreign entrants [Selected Issues, 2004: 429-438].

However, despite the successful management of the preparatory faculty by prof. Tetyana Tabenska, these two divisions remained separate. This happened because it was impossible to integrate their methodology, curriculum, the teaching staff and the other integral parts of the educational process. The main direction of scientific and methodological activity of preparatory department was the topic "Scientific and methodic basis of foreign students study on the preparatory department". Teachers of the preparatory faculty have created a set of textbooks on all subjects specially for foreign students. $27 \mathrm{PhD}$ researches on scientific and methodological problems of teaching for foreigners were completed. At the same time, there was no such scientific and methodic development and activities at the native learners' preparatory division because of some significant chairs closure [Selected Issues, 2004: 429-438].

In 2012, the preparatory department was reorganized, by division into the preparatory division (for citizens of Ukraine) and preparatory department for foreigners. In 2015, the preparatory department for foreigners was reorganized into the preparatory division.

\section{The current state of pre-university education in Ukraine}

Today, the study process for foreigners lasts for one academic year and includes, due to the Soviet model, some particular subjects (economic, natural, humanitarian and medicalbiological directions). By the 2017, when new regulations for education were implemented, foreigners were able to choose the study language (Ukrainian or Russian), which made preparatory department of Kyiv University more competitive. After the new general law for education became legitimate, Ukrainian became obligatory for all study programs, even taught in English. Nowadays the departments work on creating and implementation of the new technologies of teaching Ukrainian and Russian as foreign languages; develops plans for short-time subject studies. The department is financed by the international partners in terms of cooperation agreements. An important condition for the successful functioning of the division is a permanent staff, which may consist of qualified teachers of Ukrainian and Russian language for foreigners. The succeeding in the study depends on continuous communication but not only on teaching. In the period of independence, the educational process and models of university entrants training for Ukrainians has been modifying, due to the present educational and social conditions. The significant achievements of the period were: the consolidation of the entire educational process under one Ministry of Education and Science; the introduction of the External Independent Evaluation (EIE); the cancellation of the restriction for admission 
to more than one educational specialization per year. After the implementation of the EIE, the preparatory divisions began to compete not only with universities and with private-tutors but also with schools. Such circumstances encourage preparatory divisions to discover new forms of teaching and training methods.

The main difficulties, which university entrants come up against, are the following:

1. Despite the fact that the EIE program composed to test the results of secondary school education it requires a special effort to succeed. Each EIE subject task covers the study material of several recent years, which means a huge amount of revise. In combination with the subjects, complexity and amount of study subjects in the curriculum (23 subjects for study in 11th form) EIE appears as a serious challenge.

2. Higher education value loss. A huge amount of higher education institutions decrease a competition between institutions and between entrants.

3. Unjustifiably hyperbolized public opinion, represented by entrants' parents, about the obligingness of higher education. This problem is most common nowadays. Entrants' parents basing on their personal experience of university entry mislead their children by demanding of extra materials study, which is not actually required. At the same time, parents forget that their secondary school graduation curriculum consisted of double less quantity of subjects. Therefore, they cannot correctly estimate what amount of tasks children must successfully complete. As a result, children become apathetic to study (the "empty head" effect).

4. After the adaptation of Ukrainian educational legislation to European standards, the gap between secondary school education results and the requirements of higher education has increased. For example, in Great Britan, school education lasts 13 years. The final level A, which lasts for two years, is devoted to pre-university preparation. The number of study subjects which concern the prospective university studies is limited. A-level is taken only by pupils who contemplate entering the university. Similar principles are used in pre-university education of the USA: the high school lasts 2-3 years and of France, where lyceum education lasts 2-3 years. Therefore, a typical university prospective entrant in these countries spends last two years of school to prepare to enter university for particular study. In Ukraine, many prospective entrants come up against the difficulties in preparation to EIE. Despite of educational reforms the Soviet system of education, in which the school remains separated from academic higher education, legitimates the existence of such units as preparatory divisions. It is a rule of thumb that not all pupils are sufficiently prepared for university study, which is caused by the lack of specialized training in secondary schools.

5. The absence of an entrant's motivation because of being misled by the list of EIE subjects, which sometimes used for future profession choose. This problem is caused by several factors. The cancellation of the restriction for admission to more than one educational specialization per year makes university entry more possible, which makes prospective entrants more relaxed. Secondly, the large number of mistakes concerning university choose are caused by emotions. A lot of pupils want to be "lawyers" or "international relations professional" without consideration of having necessary abilities and knowledge for such profession. Thirdly, many entrants to university sincerely believe that the main objective is to overcome the entry barrier, or that it is easier to enter the faculty with the lowest level of competition. Only after a while, they begin to consider if their profession choice was correct. 
6. Problems in the composition and bad correlation of EIE tests. The system of EIE does not reflect the real ability to study a particular subject or a profession in university. Moreover, the arithmetic sum of points for a certificate (or the sum of weight coefficients for an EIE certificate and a secondary graduation certificate) does not indicate the ability to study a particular profession. This problem is more serious then it seems. EIE has to be coordinated with the variability of the school study program (for example, History: the test is based on several textbooks which are recommended to use in secondary school, while the particular pupil uses only one of them for study). It is also known that the "Alliance of EIE Support Program" in Ukraine is financed by the US government. However, it is difficult to build a testing system on the Soviet background and to implement it as a general system of admission to higher education institutions. This might be explained by the fact that Ukraine only "borrowed" the system of testing, which in the United States is not essential for entry to higher education. In the United States, universities provide additional tests (essays or interviews - interviews) in addition to EIE tests. However, the main obstacle on the way to solve all mentioned problems is still remaining soviet influenced elements in secondary school management. Secondary school education is still not sufficient for university entry. For this reason, entrants to university still in search for 1) individual additional study; 2) optional additional study in school; 3 ) personal tutoring or study at the preparatory division. It is well known that the study process is highly individual. Usually, the prospective entrant requires more than just additional study materials. Often the study motivation depends on the fees, which have to be paid for the individual tutoring, or on competition between classmates. Consequently, university entrants or their parents have to make a decision about the best suitable form of training, which can motivate the study.

Preparatory division has a lot of advantages in comparison with alternative forms of entrants training. Some of them are: comfortable educational environment; teaching tactics and study plans, which proved their effectiveness; permanent results and students activity monitoring, regular feedbacks. The preparatory division is targeted to bridge the gap between, the level of training in non-specialized secondary schools and the requirements of the higher education institution. The preparatory division also provides special motivation and informational activities as well as professional guiding for future university entrants. Today, the forms and methods of teaching at the preparatory division are improved, but the core remains the same: providing initial training for entrants in order to prepare them for university study; to develop independent and creative thinking, which helps to solve complicated problems. The preparatory department has several types of study: full-time, evening-time, Saturday; there are several short-term programs to study during holidays. Some courses are delivered as a part of University Colleges study. For more optimal achievement of appropriate EIE skills, there are several training tests organized, which are composed by teachers of the preparatory division. These tests are coordinated with the technical requirements of the Ukrainian Center for Educational Quality Assessment (structure and composition of the test, the number of tasks, complexity, the test time and the principles for its evaluation). Testing is carried out separately for each chapter subject as well as for the entire program. The completed test is reviewed by the teacher with an additional feedback. Such approach allows to get used to the form of EIE tests on each subject and to work out an equal strategy to complete them successfully. Teaching on preparatory division is provided by experienced subject teachers. 
The teacher's tasks are: to help in systematizing of the knowledge that students have from school; to repeat the most difficult subject sections; to provide professional training on selected subjects and individual skills. In addition, the team of the preparatory division helps the entrant to determine the future profession. During the training it is possible:

- to get information about the University — to get acquainted with the departments and specialties of the University to make the conscious choice of the future profession;

- to get knowledge and skills which become a basis of further education;

- to get used to the university study, which is fundamentally different in comparison to school. University study is prestigious and honorable as well as difficult and responsible;

- to become informed about further employment and prospects;

For professional guiding of entrants, preparatory division arranges the meetings with teachers and scientists on different fields, who work in University. Such meetings are arranged as roundtable discussions, review lectures, scientific-theoretical or practical seminars, demonstrational experiments, etc. Such meetings have a positive effect, because they help entrants to get used to the university environment.

\section{Conclusions}

Pre-university education, as an element of the higher education system of Ukraine, was founded in Soviet times but is still relevant in Post-Soviet period. Pre-university education of foreign and native entrants has different objectives, assignments, methods and study plans. We distinguished and observed several problems and peculiarities of pre-university education of Ukraine, which are urgent nowadays: 1) EIE testing programs deal with a huge amount of materials; 2) big amount of higher educational institutions, which decrease the value of higher education; 3) EIE subjects list — as a factor of professional guiding; 4) wide gap between school and university education; 5) low efficiency of EIE tests in revealing entrants talents and skills for future education. Author proposed the possible ways to resolve the mentioned problems, using the experience of preparatory department of Taras Shevchenko National University of Kyiv.

\section{미] References}

Bazaluk, Oleg, and Tetiana Matusevych. Otto Friedrich Bollnow: Search for the Fundamentals of Existential Philosophy. Annals of the University of Craiova - Philosophy Series, nr. 34 (2/2014), 2014: 5-16.

History of Ukrainian Philosophy. Student's book. [Rusin M.Y., Ogorodnyk I.V., Bondar S.V., etc.]. Kyiv, Kyiv University Press, 2008.

Liashenko, Iryna and Sergii Rudenko. The Management Features of the University Preparatory Department. Scientific Bulletin of National Mining University. Volume 1, 2018: 132138. DOI: $10.29202 /$ nvngu/2018-1/6.

Liashenko, Iryna. Wilhelm Dilthey: Understanding the Human World. Philosophy and Cosmology. Volume 20, 2018: 163-169. DOI: 10.29202/phil-cosm/20/16

Liashenko, Mykola and Sergii Rudenko. Is a New Generation of Managers Likely to Come to Small Towns of Ukraine? (An interview with Mykola Liashenko). Ukrainian Policymaker, Volume 2, 2018: 56-62. DOI: 10.29202/up/2/8 
Montgomery, Paul, and Jane Lilly. Systematic reviews of the effects of preparatory courses on university entrance examinations in high school-age students. International Journal of Social Welfare, Volume 21, 2012: 3-12. DOI:10.1111/j.1468-2397.2011.00812.x

Nelipa, Dmytro, Oleg Batrymenko, Sergii Rudenko and Iryna Liashenko. Higher education management in Ukraine: will generation change help us transform it faster? Scientific Bulletin of National Mining University. Volume 3, 2018: 167-175. DOI: 10.29202/ nvngu/2018-3/19

Rudenko, Sergii, Yaroslav Sobolievskyi and Vadym Tytarenko. Cosmology in the Philosophical Education of Ukraine: History and Modern Condition. Philosophy and Cosmology. Volume 20, 2018: 128-138. DOI: 10.29202/phil-cosm/20/12

Rudenko, Sergii, Roman Sapeńko, Oleg Bazaluk, and Vadym Tytarenko. Management Features of International Educational Projects between Universities of Poland and Ukraine. Naukovyi Visnyk Natsionalnoho Hirnychoho Universytetu. 2, 2018: 142-147. DOI: $10.29202 / \mathrm{nvngu} / 2018-2 / 21$

Selected Issues in the History of Taras Shevchenko National University of Kyiv [V.V.Rizun, M.S.Tymoshyk, A.E.Konverskyi, etc.]. Kyiv, 2004.

Svyrydenko, Denys, and Olena Yatsenko. Dialectics of Nominal and Real Power in the Ukrainian and World Politics. Ukrainian Policymaker, Volume 2, 2018: 33-40. DOI: $10.29202 / \mathrm{up} / 2 / 5$ 